\title{
Investigation of Heterotrophic Bacteria, Legionella and Free - Living amoeba in Cooling Tower Samples by FISH and Culture Methods
}

\author{
Zuhal Zeybek*, Nihal Dogruoz Gungor, Irfan Turetgen \\ Istanbul University, Faculty of Science, Department of Biology, Fundamental and Industrial Microbiology, İstanbul, Turkey
}

Please cite this article as: Zeybek Z, Dogruoz Gungor N, Turetgen I. Investigation of heterotrophic bacteria, Legionella and free - living amoeba in cooling tower samples by FISH and culture methods. Eur J Biol 2017; 76(1): 7-13.

\begin{abstract}
The microorganisms living in the cooling towers water can affect both human health through inhalation of aerosolized water as well as industrial processes. In order to analyse such man-made water systems, microbiological tests that can give results in a short time are needed. In this study, the presence of heterotrophic bacteria, Legionella bacteria and free - living amoeba, FLA, including Acanthamoeba, in cooling-tower water and biofilm samples were investigated using two different methods, fluorescent in situ hybridization (FISH), and culture. For this, a total of 40 water and biofilm samples were taken from 16 different cooling towers in Istanbul. FISH and culture analysis have revealed that the number of heterotrophic bacteria within the water and the biofilm samples was above the threshold values $\left(>10^{5}\right.$ cell. $\left.\mathrm{mL}-1\right)$, generally. Despite Acanthamoeba were present in all cooling tower specimens, Legionella pneumophila serogroup 1 were only detected in the biofilm of one cooling tower. According to the results of this study, both methods are recommended to be used in conjunction. Due to the the large biodiversity of FLA such as Hartmanella sp. and Naeglaria sp, there is a need for new studies utilizing FISH method for sensitive, reliable results in a short period of time.
\end{abstract}

Keywords: Cooling tower water, biofilm, heterotrophic bacteria, Legionella, Acanthamoeba, free-living amoebae

\section{INTRODUCTION}

Water circulation systems that reuse water are being used in various fields of the industry to reduce the water consumption. The cooling towers are one example of such systems, and they are being used in central air conditioning and telecommunication units to reduce the temperature of the water and are mostly found in large buildings such as hotels, hospitals and workplaces. Microorganisms living in various aquatic environments have the potential to survive in both cooling tower water and biofilm. They can negatively affect industrial processes and human health by inhalation of contaminated aerosols (1-5). The need for assessing the real risk values of cooling towers is closely linked to the emergence of Legionnaires Disease, which is caused by Legionella pneumophila, L. pneumophila originating from cooling tower. The presence of heterotrophic bacteria and free-living amoeba, FLA, is also considered as one of the risk factors in the cooling waters. Therefore, most of the developed countries have prepared new laws and regulations to use biocides in the cooling towers to keep these microorganisms under control (6-8). Turkey has published a special program conducted by the Ministry of Health "Legionnaires Disease Control Regulation on the Principles and Procedures" on 13/05/2015 (9). There are two main ecological factors which may lead to the increased risk of Legionnaires' Disease. The first is the presence of $L$. pneumophila with the protozoa like FLA within the biofilm, and the second is the separation of these bacteria from the biofilm to pass into the aqueous phase $(10,11)$. FLA have large biodiversity, both having their own pathogenicity and creating different pathogenicities as a host to other heterotrophic bacteria and Legionella to protect them from the harmful effects of biocides. Thus, FLA have emerged as an important issue (12-20). Just like Legionella bacteria residing in cooling towers, the high numbers of heterotrophic bacteria are also an important criteria for determining the water quality. Since some of these microorganisms are opportunistic pathogens, they 
may create risks for human health conditions $(3,21)$. Usually, the harmful effects of these bacteria are not realized well enough due to their massive distribution in nature. However, they may cause severe infections within the systems like cooling towers because they find the suitable conditions to replicate. Our study shows the presence of heterotrophic bacteria, L. pneumophila serogroup 1, and Acanthamoeba genus (FLA) in the cooling tower waters and in the biofilm layer detected using a novel approach involving both traditional culture method and molecular method fluorescence in situ hybridization FISH.

\section{MATERIALS AND METHODS}

\section{Sampling}

A total of 40 samples (20 bulk water and 20 biofilm samples) were collected from the cooling towers of 16 different buildings (hotel, workplace, industrial building). The water samples were then placed into sterile plastic containers $(3 \mathrm{~L})$, and the biofilm samples $\left(10 \mathrm{~cm}^{2}\right)$ were taken by sterile swab to transfer the content into a centrifuge tube containing $20 \mathrm{~mL}$ tap water. The samples were brought back to the laboratory as soon as possible. The 3 liters of water sample was filtered using a sterile nylon filter (142 mm diameter, 0,22 $\mu \mathrm{m}$ porous diameter) and sterile steel filtration system (Sartorius, Sredim Biotech $\mathrm{GmbH}$, Goettingrn, Germany). Then, this nylon filter was placed in a 20 $\mathrm{mL}$ sterile water containing sterile bag in the stomacher device (IUL Instruments). By stomaching the bag about $1 \mathrm{~min}$, the bacteria inside the filter was passed into the water phase. The biofilm samples were taken into the centrifuge tube, and vortexed for $1 \mathrm{~min}$ to homogenize the content.

All water and biofilm samples had undergone the following processes; a) They were used for examining all the microorganisms' culture methods, b) They were stored at $-20^{\circ} \mathrm{C}$ after the $1: 1$ ratio addition of $50 \%$ ethanol to be used in the FISH method later on.

\section{The Examination of Water Samples by Culture Method}

For the heterotrophic bacteria isolation and counting, serial dilution was made $\left(10^{-1}-10^{-10}\right)$ to concentrated samples within the bag as mentioned above. $0.1 \mathrm{~mL}$ of each dilution were placed into the R2A agar medium triplicate, incubated for $7 \mathrm{~d}$ at $27^{\circ} \mathrm{C}$ in Petri dishes, and then the colonies were counted as described previously (22).

For isolation and counting of Legionella bacteria, $10 \mathrm{~mL}$ of the concentrated samples were centrifuged at $6000 \mathrm{rpm}$ for 15 minutes. Then $1: 1$ of $\mathrm{HCl}-\mathrm{KCl}(\mathrm{pH}: 2.2)$ acid mixture was added for 20 minutes. Then it was inoculated into buffered charcoal yeast extract (BCYE) agar supplemented with glycine, vancomycin, polymyxin, natamycin (GVPN). The remaining sample in the suspension was heat-treated for 30 minutes at $50^{\circ} \mathrm{C}$, and was inoculated to BCYE agar supplemented with GVPN. All cultivations were carried out in 3 replicates and incubated at $37^{\circ} \mathrm{C}$ for $14 \mathrm{~d}$. Colony morphology and Gram staining were examined and colonies were inoculated into Trypton Soy Agar (TSA) were picked from colonies similar to L. pneumophila bacteria. When there was no growth in TSA medium, Legionella Latex Test Kit (Oxoid) was used for serological identification using slide agglutination method (23).

For the FLA isolation, $100 \mathrm{~mL}$ water sample was filtered through $0.45 \mu \mathrm{m}$ diameter porous sterile membrane, and then the filter was placed upside down on top of the $E$. coli spreaded non-nutrient agar (NNA) in Petri dish. The experiments were done in triplicates. Petri dishes were stored for $10 \mathrm{~d}$ at $30^{\circ} \mathrm{C}$ and examined daily with a light microscope using $10 \mathrm{X}$ magnification (24).

\section{Examination of Biofilm Samples by Culture Method}

For the isolation and counting of heterotrophic bacteria, 0.1 $\mathrm{mL}$ of R2A agar broth from serial dilutions $\left(10^{-1}-10^{-10}\right)$ prepared from the suspension of homogenized biofilm was used and triplicate cultivations were carried out. Cultures were incubated at $27^{\circ} \mathrm{C}$ for $7 \mathrm{~d}$ and colony count was performed in Petri dishes.

For the isolation and counting of Legionella bacteria, $0.1 \mathrm{~mL}$ of the homogenized biofilm suspension was inoculated into BCYE agar supplemented with GVPN directly and after treatment with acid and heat as described above. After $14 \mathrm{~d}$ of incubation at $37^{\circ} \mathrm{C}$ the colonies were counted.

For FLA culture, $20 \mu \mathrm{l}$ of the suspended biofilm samples were plated onto the surface of the E. coli spreaded NNA in Petri dish. All cultures were kept at $30{ }^{\circ} \mathrm{C}$ for $10 \mathrm{~d}$. It was daily examined under light microscope (x10). Experiments were performed in 3 triplicates (24).

\section{The Examination of Water and Biofilm Samples via FISH Method}

All samples were taken out of the $-20^{\circ} \mathrm{C}$ storage, thawed, and then examined using FISH method for Legionella, heterotrophic bacteria and Acanthamoeba (25-27).

Oligonucleotides: Following oligonucleotide probes were used (26,28-30): a) FAM- labelled ACANTHA probe and CY3labelled EUK 516 (positive control) probes for the examination of Acanthamoeba, b) CY3 labelled EUB 338 probe for the examination of heterotrophic bacteria, and c) CY3-targeted LEGPNE1 probe for the examination of L. pneumophila. NON 338 probe was used for non-specific binding as a negative control (Table 1).

FISH Method: Both water samples and biofilm specimens were fixed in 4\% paraformaldehyde (PFA) for all bacteria and in $2 \%$ PFA for Acanthamoeba genus overnight at $4{ }^{\circ} \mathrm{C}$. After fixation, samples were washed triplicate in 1xPBS (for bacteria: 13000 rpm, for Acanthamoeba: $8230 \mathrm{rpm}$ ), and then the samples were placed into the wells of polytetrafluoroethylene coated slides to dry. The dried slides were dehydrated at $46^{\circ} \mathrm{C}$ with varying alcohol percentages of $50 \%, 80 \%, 96 \%$ for 3 minutes. The targeted fluorescence labeled probes (for the bacteria $50 \mathrm{ng} / \mu \mathrm{L}$, for Acanthamoeba type $150 \mathrm{ng} / \mu \mathrm{L}$ ) specific to the microorganism (Table 1) and hybridization buffer $(0.9 \mathrm{M} \mathrm{NaCl}, 20 \mathrm{mM}$ Tris/ $\mathrm{HCl}$, 
$0.01 \%$ SDS) that includes $20 \%$ formamide was added into each well and incubated for $24 \mathrm{~h}$ in dark and humid medium for hybridization.

At the end of $24 \mathrm{~h}, 2 \mu \mathrm{L}$ of DNA binding stain 6-diamino-2-phenylindole, DAPI, was added and samples were incubated for $30 \mathrm{~min}$. Then they were washed with washing buffer (20 mM Tris/ $\mathrm{HCl}, \mathrm{pH} 7.6,0.01 \%$ sodium dodecyl sulfate, $5 \mathrm{mM}$ EDTA, $160 \mathrm{mM} \mathrm{NaCl}$ ) at $46^{\circ} \mathrm{C}$ for $15 \mathrm{~min}$. The final washing was completed with bi-distilled water at $4{ }^{\circ} \mathrm{C}$ for $10 \mathrm{~min} .5 \mu \mathrm{L}$ of anti-fading solution was added to the dried slides, and samples were examined immediately under the epifluorescence microscope (Nikon Eclipse 80i). Acanthamoeba castellanii, A. castellanii, ATCC 50373, L. pneumophila serogroup 1 ATCC 33152 were used as positive control. The wells solely included probe and hybridization buffer, but not the microorganisms were considered as the negative controls. All of the measurements were done in triplicates.

Table 1. The probes that were used in FISH method

\begin{tabular}{lcc}
$\begin{array}{l}\text { Probe } \\
\text { Code }\end{array}$ & \multicolumn{1}{c}{$\begin{array}{c}\text { Oligonucleotides } \\
\text { LEGPNE1 }\end{array}$} & $\begin{array}{c}\text { Florescent } \\
\text { DYE }\end{array}$ \\
\hline Non 338 & 5'ATC TGA CCG TCC CAG GTT-3' $^{\prime}$-ACCT ACG GGA GGC AGC-3' & CY3-5' \\
\hline EUB 338 & 5' GCT GCC TCC CGT AGG AGT- 3' & CY3-5' \\
\hline ACANTHA & 5' TTC ACG GTA AACGAT CTG GGC C-3' & FAM-5' \\
\hline EUK 516 & 5'- ACC AGA CTT GCC CTC C-3' & CY3-5' \\
\hline
\end{tabular}

\section{Statistical Analysis}

Heterotrophic bacterial culture and the FISH numbers were compared using a t-test. Differences between variables were considered significantly different when $p<0.5$. Statistical analyses were performed using Statistical Package for Social Sciences version 11.0 (SPSS Inc.; Chicago, IL, USA) program.

\section{RESULTS}

Numbers of heterotrophic bacteria colonies (CFU) and the FISH results from bulk water (S1-S20) and biofilm samples (B1-B20) taken from cooling towers are shown in Table 2.

Our results suggest among all of the samples from all of the cooling towers, high number of aerobic heterotrophic bacteria were detected. S18 has shown the lowest number of heterotrophic bacteria $\left(1.5 \times 10^{4} \mathrm{CFU} . \mathrm{mL}^{-1}\right)$ within the water samples examined according to the culture method, whereas S9 had the highest bacteria numbers $\left(2.7 \times 10^{8} \mathrm{CFU} \cdot \mathrm{mL}^{-1}\right)$. For the biofilm samples, B15 has shown the lowest number among heterotrophic bacteria $\left(3 . \times 10^{3} \mathrm{CFU} / \mathrm{cm}^{2}\right)$ while the $\mathrm{B} 1$ had the highest amount heterotrophic bacteria $\left(4.5 \times 10^{7} \mathrm{CFU} / \mathrm{cm}^{2}\right)$. Congruent with the results of culture method, FISH evaluation of the same samples has revealed that $\mathrm{S} 18$ has shown the lowest number of heterotrophic bacteria $\left(5 \times 10^{4}\right.$ cell. $\left.\mathrm{mL}^{-1}\right)$ in the aqueous sample while 59 had the highest heterotrophic bacteria number $\left(2.8 \times 10^{8}\right.$ cell. $\left.\mathrm{mL}^{-1}\right)$. For the biofilm samples, B5 had the lowest number of heterotrophic bacteria $\left(3 . \times 10^{7} \mathrm{cell} / \mathrm{cm}^{2}\right), \mathrm{B} 16$ showed the highest heterotrophic bacteria number $\left(3.6 \times 10^{9} \mathrm{cell} / \mathrm{cm}^{2}\right)$.

Table 2. Total heterotrophic bacteria that were observed in the bulk water and biofilm samples

\begin{tabular}{|c|c|c|c|c|c|c|c|}
\hline \multirow[b]{2}{*}{$\begin{array}{l}\text { Water samples } \\
\text { (code) }\end{array}$} & \multirow{2}{*}{\multicolumn{2}{|c|}{$\begin{array}{c}\text { CULTURE } \\
\begin{array}{c}\text { Biofilm samples } \\
\text { (code) }\end{array}\end{array}$}} & \multirow[b]{2}{*}{$\mathrm{CFU} / \mathrm{cm}^{2}$} & \multicolumn{3}{|c|}{ FISH } & \multirow[b]{2}{*}{$\mathrm{cell} / \mathrm{cm}^{2}$} \\
\hline & & & & $\begin{array}{c}\text { Water samples } \\
\text { (code) }\end{array}$ & cell. $\mathrm{mL}^{-1}$ & $\begin{array}{c}\text { Biofilm samples } \\
\text { (code) }\end{array}$ & \\
\hline S1 & $4.7 \times 10^{5}$ & B1 & $4.5 \times 10^{7}$ & S1 & $1.5 \times 10^{6}$ & B1 & $6.2 \times 10^{7}$ \\
\hline S2 & $1.7 \times 10^{5}$ & B2 & $3 \times 10^{7}$ & $\mathrm{~S} 2$ & $3.9 \times 10^{5}$ & B2 & $1.7 \times 10^{8}$ \\
\hline S3 & $1,9 \times 10^{5}$ & B3 & $1.5 \times 10^{7}$ & S3 & $1.2 \times 10^{6}$ & B3 & $3.9 \times 10^{8}$ \\
\hline S4 & $1.6 \times 10^{4}$ & B4 & $2.2 \times 10^{7}$ & S4 & $3.7 \times 10^{5}$ & B4 & $3 . \times 10^{8}$ \\
\hline S5 & $1.7 \times 10^{4}$ & B5 & $2 \times 10^{7}$ & S5 & $7.5 \times 10^{5}$ & B5 & $3 . \times 10^{7}$ \\
\hline S6 & $1.5 \times 10^{8}$ & B6 & $4.6 \times 10^{5}$ & S6 & $1.6 \times 10^{8}$ & B6 & $7.5 \times 10^{7}$ \\
\hline S7 & $1.9 \times 10^{7}$ & B7 & $9.1 \times 10^{4}$ & S7 & $2.1 \times 10^{8}$ & B7 & $1.2 \times 10^{9}$ \\
\hline S8 & $2 \times 10^{8}$ & B8 & $9.6 \times 10^{4}$ & S8 & $2.4 \times 10^{8}$ & B8 & $1.4 \times 10^{8}$ \\
\hline S9 & $2.7 \times 10^{8}$ & B9 & $4.2 \times 10^{5}$ & S9 & $2.8 \times 10^{8}$ & B9 & $9.5 \times 10^{8}$ \\
\hline $\mathrm{S} 10$ & $2.4 \times 10^{7}$ & B10 & $9 \times 10^{4}$ & $\mathrm{~S} 10$ & $2.5 \times 10^{7}$ & B10 & $1.1 \times 10^{8}$ \\
\hline $\mathrm{S} 11$ & $2.2 \times 10^{7}$ & B11 & $1.9 \times 10^{4}$ & $\mathrm{~S} 11$ & $2.9 \times 10^{7}$ & B11 & $8.2 \times 10^{8}$ \\
\hline $\mathrm{S} 12$ & $1.7 \times 10^{7}$ & B12 & $3.9 \times 10^{4}$ & $\mathrm{~S} 12$ & $2.3 \times 10^{7}$ & B12 & $3.7 \times 10^{8}$ \\
\hline $\mathrm{S} 13$ & $1.4 \times 10^{7}$ & B13 & $2.4 \times 10^{4}$ & $\mathrm{~S} 13$ & $1.6 \times 10^{7}$ & B13 & $3.8 \times 10^{8}$ \\
\hline S14 & $3.8 \times 10^{7}$ & B14 & $1.6 \times 10^{4}$ & $\mathrm{~S} 14$ & $4.2 \times 10^{7}$ & B14 & $9.2 \times 10^{8}$ \\
\hline $\mathrm{S} 15$ & $1.4 \times 10^{7}$ & B15 & $3 \times 10^{3}$ & S15 & $1.7 \times 10^{7}$ & B15 & $7.7 \times 10^{7}$ \\
\hline S16 & $1.5 \times 10^{7}$ & B16 & $1.2 \times 10^{7}$ & $\mathrm{~S} 16$ & $1.6 \times 10^{7}$ & $\mathrm{~B} 16$ & $3.6 \times 10^{9}$ \\
\hline S17 & $1.3 \times 10^{7}$ & B17 & $7.2 \times 10^{6}$ & $\mathrm{~S} 17$ & $2.1 \times 10^{7}$ & B17 & $1.1 \times 10^{9}$ \\
\hline S18 & $1.5 \times 10^{4}$ & B18 & $1.2 \times 10^{5}$ & S18 & $5 \times 10^{4}$ & B18 & $2.3 \times 10^{8}$ \\
\hline S19 & $1.9 \times 10^{6}$ & B19 & $2.2 \times 10^{5}$ & S19 & $2.8 \times 10^{6}$ & B19 & $1.7 \times 10^{8}$ \\
\hline S20 & $2.2 \times 10^{5}$ & B20 & $5.8 \times 10^{4}$ & $\mathrm{~S} 20$ & $3.8 \times 10^{5}$ & B20 & $6.1 \times 10^{7}$ \\
\hline CFU: colony form & & & & & & & \\
\hline
\end{tabular}



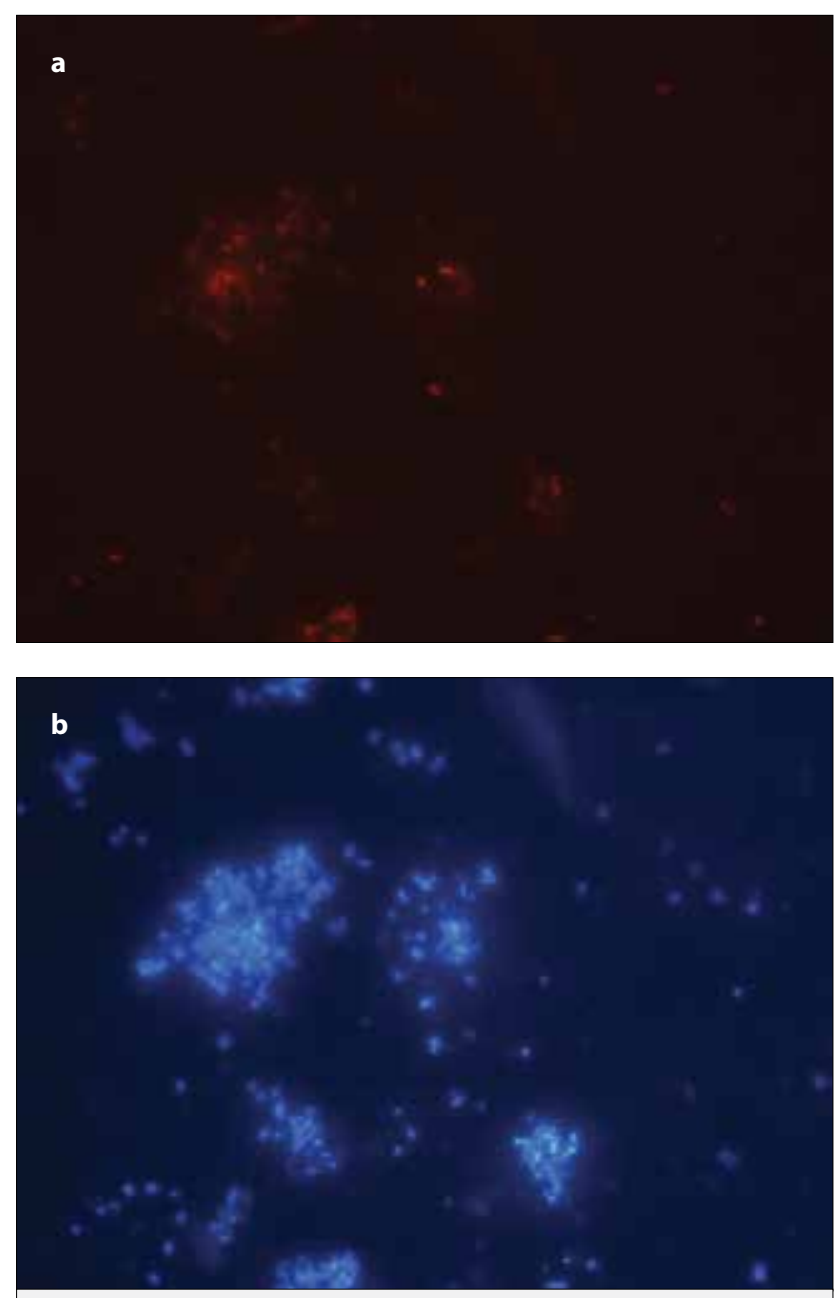

Figure 1. a, b. The images of epifluorescence microscopic of heterotrophic bacteria (x1000). (a) CY3 labeled EUB 338, (b) with DAPI

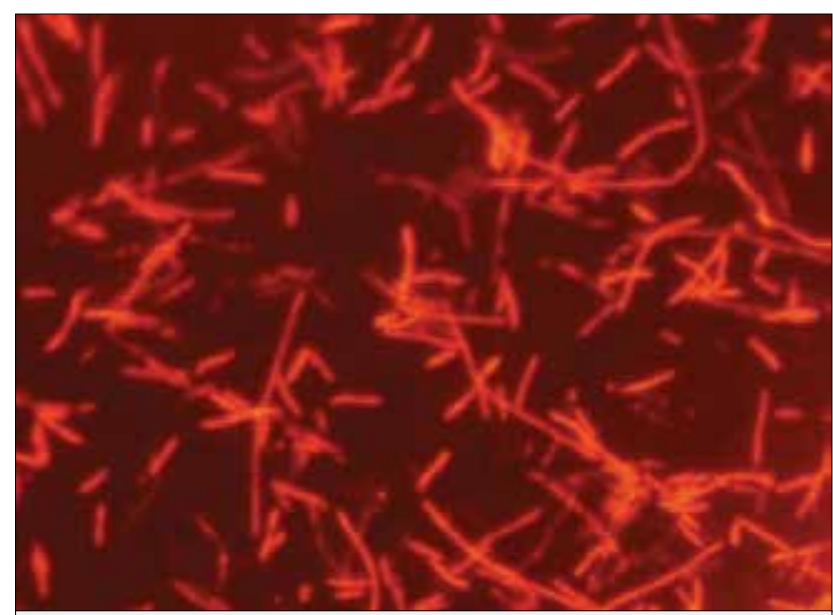

Figure 2. The images of epifluorescence microscopic of Legionella bacteria, CY3 labeled LEG PNE1 probe (x1000).

Figure 1 shows the epifluorescence microscopic images of heterotrophic bacteria with varying morphologies examined using

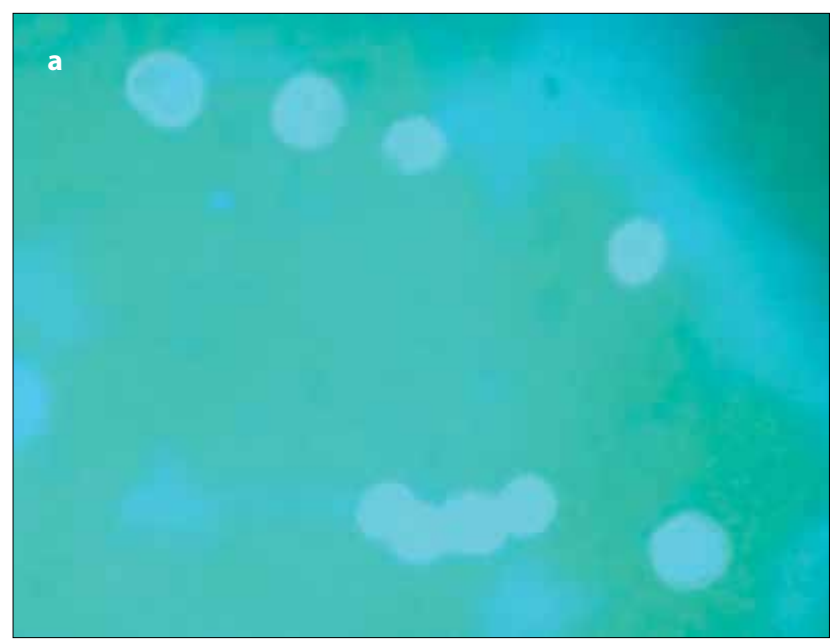

b

Figure 3. a, b.The epifluorescence microscope image of Acanthamoeba (x500). (a) FAM -labeled ACANTHA, (b) DAPI- labeled ACANTHA.

FISH. Our results revealed that the number of heterotrophic bacteria in cultures of from bulk water and from biofilm samples were significantly lower than those detected in FISH counts $(p<0.5)$.

Legionella bacteria were detected only in one cooling tower biofilm sample (B3), detected by both culture $\left(742 \mathrm{CFU} / \mathrm{cm}^{2}\right.$ ) and FISH (12560 cell/ $\left.\mathrm{cm}^{2}\right)$. These bacteria were identified serologically as $L$. pneumophila serogroup 1 . The epifluorescence microscopic image of $L$. pneumohila bacteria examined via FISH method is shown in Figure 2.

The presence of FLA using culture and FISH method in water (S1-S20) and biofilm (B1-B20) samples are shown in Table 3. FLA was found in all water and biofilm samples as examined using culture method. However, culture method was not sufficient to determine the numbers and types of largely biodiverse FLA. FISH method revealed that FLA belonging to Acanthamoeba genus were present in all samples except two biofilm samples, B13 and B14. Figure 3 shows the epifluorescence microscope image of Acanthamoeba. 
Eur J Biol 2017; 76(1): 7-13

Zeybek et al. Investigation of Different Microorganisms with FISH and Culture Methods

\begin{tabular}{|c|c|c|c|c|c|c|c|}
\hline \multirow[b]{2}{*}{$\begin{array}{l}\text { Water samples } \\
\text { (code) }\end{array}$} & \multicolumn{3}{|c|}{ CULTURE } & \multicolumn{4}{|c|}{ FISH (Acanthamoeba) } \\
\hline & cell. $100 \mathrm{~mL}^{-1}$ & $\begin{array}{c}\text { Biofilm samples } \\
\text { (code) }\end{array}$ & cell $/ \mathrm{cm}^{2}$ & $\begin{array}{c}\text { Water samples } \\
\text { (code) }\end{array}$ & cell. $\mathrm{mL}^{-1}$ & $\begin{array}{c}\text { Biofilm samples } \\
\text { (code) }\end{array}$ & cell $/ \mathrm{cm}^{2}$ \\
\hline S1 & + & B1 & + & S1 & 4.2 & B1 & 319.6 \\
\hline S2 & + & B2 & + & $\mathrm{S} 2$ & 5.9 & B2 & 719.2 \\
\hline S3 & + & B3 & + & S3 & 162 & B3 & 1198.8 \\
\hline S4 & + & B4 & + & S4 & 126 & B4 & 479.5 \\
\hline S5 & + & B5 & + & S5 & 4.5 & B5 & 239.7 \\
\hline S6 & + & B6 & + & S6 & 3.2 & B6 & 263.7 \\
\hline S7 & + & B7 & + & S7 & 63 & B7 & 583.4 \\
\hline S8 & + & B8 & + & S8 & 5.5 & B8 & 911 \\
\hline S9 & + & B9 & + & S9 & 24.7 & B9 & 1166.8 \\
\hline $\mathrm{S} 10$ & + & B10 & + & $\mathrm{S} 10$ & 62.1 & B10 & 239.7 \\
\hline S11 & + & B11 & + & $\mathrm{S} 11$ & 4.1 & B11 & 79.9 \\
\hline $\mathrm{S} 12$ & + & B12 & + & $\mathrm{S} 12$ & 5.5 & B12 & 159.8 \\
\hline S13 & + & B13 & + & S13 & 18.3 & B13 & 0 \\
\hline S14 & + & B14 & + & S14 & 11.6 & B14 & 0 \\
\hline S15 & + & B15 & + & S15 & 16.4 & B15 & 799.2 \\
\hline S16 & + & B16 & + & S16 & 44 & B16 & 1518 \\
\hline S17 & + & B17 & + & S17 & 70.9 & B17 & 1334.6 \\
\hline $\mathrm{S} 18$ & + & B18 & + & $\mathrm{S} 18$ & 4 & B18 & 639 \\
\hline S19 & + & B19 & + & $\mathrm{S} 19$ & 12.1 & B19 & 1814 \\
\hline S20 & + & B20 & + & $\mathrm{S} 20$ & 38.1 & B20 & 183.8 \\
\hline (+): Growth & & & & & & & \\
\hline
\end{tabular}

\section{DISCUSSION}

Microorganisms living in different water systems exhibit variety in terms of threshold limit numbers and types. For the microbial load of water system, biocide compatibility is measured and to do this, the total number of microorganisms are measured. As an example, in a closed cooling tower, the numbers of bacteria should not exceed the limit of 100.000 cell.mL $\mathrm{mL}^{-1}(3,4)$. The water and biofilm samples we have examined via culture and FISH method were from cooling towers, and the numbers of heterotrophic bacteria had exceeded the limits. The disinfection methods applied to the cooling towers did not have an optimum condition. However, the biocide application are still in progress (19). During our samplings, we have learned verbally that some various biocides were applied in different time periods to the cooling towers and on behalf of the data we have, we consider that these applications are not well enough. The culture method is still the golden standard for detection of heterotrophic bacteria number's in cooling tower samples. On the other hand, the numbers of heterotrophic bacteria in all of the biofilms detected via FISH method had greater numbers than the culture method. This could be due to entering to the viable but not-culturable phase (VBNC) (31). Therefore, it was thought that FISH is a better method in order to detect heterotrophic bacteria in the cooling towers, which was also supported by the statistical analysis. Heterotrophic bacterial numbers detected by FISH method were significantly higher than those revealed by culture method.
There was no Legionella growth out of the examined cooling tower water. However, only one of the biofilm samples had shown Legionella growth as detected both culture and FISH method. One of the reasons may be the inhibitory effects of other microorganisms in which Legionella bacteria interact with in their environment $(32,33)$. Hence, this gets proven by the increased number of heterotrophic bacteria in our study. Since these other microorganisms interacting Legionella have excess numbers compared to Legionella, they might have shown antagonistic effect on Legionella's growth. To gain deeper insights into this issue, new studies concerning the conventional culturing or FISH methodologies or PCR based molecular methods are now emerging to identify heterotrophic bacteria. One exceptional reason for using FISH to identify Legionella bacteria in this study is the potential interaction of FLA with bacteria. FLA can uptake Legionella bacteria, and protect them from the harmful environment, such as the effects of biocides and thus leading intracellular growth of Legionella bacteria. Bacteria that are growing this way, when the conditions of the outside becomes proper enough, lyse the amoeba cells, and spread out $(13,16)$. Despite we have came across Acanthamoeba type FLA in all of the water samples, only one sample had the Legionella bacteria which brings the possibility of intracellular entrapment within the FLA. To make sure whether these Legionella bacteria are getting located inside FLA or not, new studies are required using the FISH method.

Current culture methods for morphological identification and FLA counting requires lots of effort, time and hence becomes 
inadequate (34). Our study did not included FLA identification with culture method. However, by examining the samples with the FISH method using the ACANTHA probe, both the presence of the Acanthamoeba genus in the samples and the knowledge of the numbers were obtained shortly. Therefore, our study suggests that the detection of Acanthamoeba using FISH method has advantages than the culture method to examine the water and biofilm samples from cooling towers. The greatest advantage of using oligonucleotide probes and FISH method is the detection of FLA in situ, and having the opportunity to classify the organism simultaneously (29). For this reason, new FISH-based studies are being planned to investigate the presence / number of other genus (etc. Hartmanella sp., Naeglaria sp.) belonging to large variety of FLA that can affect the microbial load in cooling towers. However, the microorganisms cannot be stored after being used in FISH. In fact, in the future studies, the research of the pathogenicity and disinfection of these microorganisms will be required. Therefore, the strains that will be attained depending on culture methods, will be needed. From this perspective, the culture method has more advantage over the other. As a result, to be able to measure microbial load and the microbial contamination that might be caused from the cooling tower or in case of an epidemic situation, without losing time, the microorganism/microorganisms should be detected. Thus as our data were also able to demonstrate, FISH analysis should be used to acquire results in a shorter time compared to the culture method.

Acknowledgements: This research was supported by Istanbul University Scientific Research Projects Coordination Unit (Project No: 2435).

\section{REFERENCES}

1. Kimiran Erdem A, Sanli Yurudu NO, Arslan Aydogdu EO, Dogruoz Gungor N, Zeybek Z, Turetgen I, et al. Quantitative microbiological analysis of biofilm communities from the surfaces of different cooling tower materials. IUFS J Biol 2008; 67(1): 9-16.

2. Minnos B, llhan Sungur E, Cotuk A, Dogruoz Gungor N, Cansever N. The corrosion behaviour of galvanized steel in cooling tower water containing a biocide and a corrosion inhibitor. Biofouling 2013; 29 (3): 223-35. [CrossRef]

3. Samimi A. Microorganisms of cooling tower problems and how to manage Them. Int J Basic Appl Sci 2013; 1: 705-15.

4. Sanlı Yurudu NO. Sogutma kulesi dezenfeksiyonunda is sagligi ve guvenligi. Tes Müh 2015a; 146: 13-23.

5. Turetgen I, Sungur El, Cotuk A. Enumeration of Legionella pneumophila in cooling tower water systems. Environ Monit Assess 2005; 100(1-3): 53-8. [CrossRef]

6. Miller RD, Kenepp KA. Risk Assesments for Legionnaires Disease based on routine surveillance of cooling towers for Legionellae. In: Barbaree, J.M., Breiman, R.F., Dufour, R.F(eds.), Legionella Current Status and Emerging Perspectives, ISBN 1-55581-055-1, 40-43, ASM, USA, 1993.

7. South Australian Public Health Regulations https://www.legislation.sa.gov.au/LZ/C/R/SOUTH\%20AUSTRALIAN\%20PUBLIC\%20 HEALTH\%20(LEGIONELLA)\%20REGULATIONS\%202013/CURRENT/2013.42.UN.PDF (2017, March 29) 2013.
8. Nalco, Australian Standards Maintaining Cooling Water Systems, http://www.ihea.org.au/files/sa/maintenance_of_cooling_water_ systems.pdf (2017, March 14) 2015.

9. Sanli Yurudu NO. Lejyoner Hastalıgı Kontrol Usul ve Esasları Hakkinda Yonetmelik" ile llgili Bilgilendirme. Tes Muh 2015; 149: 33-36.

10. Kuiper MW, Wullings B, Akkermans ADL, Beumer RR, Kooij D. Intracellular proliferation of Legionella pneumophila in Hartmannella vermiformis in aquatic biofilms grown on plasticized polyvinyl chloride. Appl Environ Microbiol 2004; 70(11): 6826-33. [CrossRef]

11. Storey MV, Ashbolt NJ, Stenstrom TA. Biofilms, thermophilic amoebae and Legionella pneumophila - a quantitative risk assessment for distributed water. Water Sci Technol 2004; 50(1): 77-82.

12. Barbeau J, Buchler T. Biofilm augment the number of free-living amoebae in dental unit waterlines. Res Microbiol 2001; 152(8): 753-60. [CrossRef]

13. Declerck P, Behets J, Lammertyn E, Ollevier F. Acanthamoeba castellanii strongly increases the number of Legionella pneumophila in model tap water biofilms. In: Cianciotto, N., Kwaik, Y. A, Edelstein, P., Fields, B., Geary, D., Harrison, T., Joseph, C., Ratcliff, R. M., Stout, J. E., Swanson, M. S. (eds), Legionella: State of the Art 30 Years after Its Recognition, 395- 397, Washington, D.C. 2006. [CrossRef]

14. Horn M, Wagner M. Bacterial endosymbionts of FLA. J Eukaryot Microbiol 2004; 51(5): 3-16. [CrossRef]

15. Molmeret M, Horn M, Wagner M, Santic M, Abu Kwaik Y. Amoeba as training grounds for intracellular bacterial pathogens. Appl Environ Microbiol 2005; 71(1): 20-8. [CrossRef]

16. Rowbotham TJ. Preliminary report on the pathogenity of Legionella pneumophila for freshwater and soil amoebae. J Clin Pathol 1980; 33(12): 1179-83. [CrossRef]

17. Rodriguez-Zaragoza S. Ecology of free-living amoebae. Crit Rev Microbiol 1994; 20(3): 225-41. [CrossRef]

18. Scheikl U, Sommer R, Kirschner A, Rameder A, Schrammel B, Zwimuller I, et al. Free-living amoeba (FLA) co-occuring with legionella in Industrial waters . Eur J Prositol 2014; 50(4): 422-9. [CrossRef]

19. ScheikI U, Tsao HF, Horn M, Indra A, Walochnik J. Free-living amoeba and their associated bacteria in Austrian cooling towers: A 1 year routine screening. Parasitol Res 2016; 115(9): 3364-75. [CrossRef]

20. Thomas JM, Ashbolt NJ. Do free-living amoebae in treated drinking water systems present an emerging health risk. Environ Sci Technol 2011; 45(3): 860-9. [CrossRef]

21. Huck PM, Gagnon G. Understanding the distribution system as a bioreactor: a framework for managing heterotrophic plate count levels. Int J Food Microbiol 2004; 92(3): 347-53. [CrossRef]

22. Reasoner DJ, Geldrich EE. A new medium for the enumeration and subculture of bacteria from potable water. Appl Environ Microbiol 1985; 49(1): 1-7.

23. British Standard. Water quality part 4: Microbiological methods, detection and enumeration of Legionella. BS 6068-4.12:2004, ISO 11731. 1998.

24. National Standard Method. Isolation and identification of Acanthamoeba species. Issued by standards unit, evaluations, and standards laboratory on behalf of the water working group and the environmental surveillance unit, CDSC, W 17i2.3, 1-12. 2005

25. Grimm D, Merkert H, Ludwig W, Schleifer, KH, Hacker J, Brand BC. Specific detection of Legionella pneumophila: construction of a new $16 \mathrm{~S}$ rRNA-targeted oligonucleotide probe. Appl Environ Microbiol 1998; 64(7): 2686-90.

26. Grimm D, Ludwig W, Brandt BC, Michel R, Schleıfer KH, Hacker J, Steınert M. Development of $18 \mathrm{~S}$ rRNA-targeted oligonucleotide probes for specific detection of Hartmannella and Naegleria in Legionella - positive environmental samples. Syst Appl Microbiol 2001; 24(1): 76-82. [CrossRef] 
27. Manz W, Amann R, Szewzyk R, Szewzyk U, Stenstrom TA, Hutzler $P$, et al. In situ identification of Legionellaceae using $16 \mathrm{~S}$ rRNA targeted oligonucleotide probes and confocal laser scanning microscopy. Microbiology 1995; 141 (Pt 1): 29-39. [CrossRef]

28. Gescher DM, Kovacevic D, Schmiedel D, Siemoneit S, Mallmann C, Halle $\mathrm{E}$, et al. Fluorescence in situ hybridisation (FISH) accelerates identification of Gram-positive cocci in positive blood cultures. Int J Antimicrob Agents 2008; 32S: S51-S59. [CrossRef]

29. Stothard DR, Hay J, Schroeder-Dıedrıch JM, Seal DV, Byers TJ. Fluorescent oligonucleotide probes for clinical and environmental detection of Acanthamoeba and the T4 18S rRNA gene sequence type. J Clin Microbiol 1999; 37(8): 2687-93.

30. Wallner G, Amann R, and Beisker W. Optimizing fluorescent in situ hybridization with rRNA-targeted oligonucleotide probes for flow cytometric identification of microorganisms. Cytometry 1993; 14(2): 136-43. [CrossRef]

31. Gauthier MJ. Environmental parameters associated with the viable but nonculturable state. In: R. Colwell and D. Jay Grimes (eds.), Nonculturable microorganisms in the environment, Chapter 7, 87112, ASM Press, Washington DC. 2000. [CrossRef]

32. Cotuk A, Dogruoz Gungor N, Zeybek Z, Kimiran Erdem A, Ilhan Sungur $E$. The effects of Pseudomonas and Aeromonas strains on Legionella pneumophila growth. Ann Microbiol 2005; 55(3): 219-24.

33. Kimura $S$, Tateda $K$, Ishii $Y$, Horikawa $M$, Miyairi $S$, Gotoh $N$, et al. Pseudomonas aeruginosa Las quorumsensing autoinducer suppresses growth and biofilm production in Legionella species. Microbiology 2009; 155(Pt 6): 1934-9. [CrossRef]

34. Smirnow AV, Brown S. Guide to the methods of study and identification of soil gymnamoebae. Protistology 2004; 3(3): 148-90. 